\title{
Assessment of Irrigation Water Quality Parameters of Nyandungu Wetlands
}

\section{Phenias Mukiza1 ${ }^{*}$, Jean De Dieu Bazimenyera ${ }^{1}$, Jean Paul Nkundabose ${ }^{2}$, Rose Niyonkuru ${ }^{1}$, Nelly Elias Bapfakurera ${ }^{1}$}

${ }^{1}$ Department of Irrigation and Drainage College of Agriculture, Animal Sciences and Veterinary Medicine, University of Rwanda, Musanze, Rwanda

${ }^{2}$ School of Environmental Science and Engineering, Suzhou University of Science and Technology, Suzhou, China

Email: *pheniasmukiza1@gmail.com

How to cite this paper: Mukiza, P., Bazimenyera, J. D. D., Nkundabose, J. P., Niyonkuru, R., \& Bapfakurera, N. E. (2021). Assessment of Irrigation Water Quality Parameters of Nyandungu Wetlands. Journal of Geoscience and Environment Protection, 9, 151-160.

https://doi.org/10.4236/gep.2021.910011

Received: September 8, 2021

Accepted: October 26, 2021

Published: October 29, 2021

Copyright $\odot 2021$ by author(s) and Scientific Research Publishing Inc. This work is licensed under the Creative Commons Attribution International License (CC BY 4.0)

http://creativecommons.org/licenses/by/4.0/ (c) (i) Open Access

\begin{abstract}
The present paper sought to assess some physico-chemical parameters above permissible guidelines of irrigation water standard, the study was carried during establishment of Ecotourism Park. The field survey design was used and it was accompanied by laboratory tests to analyze the levels of physico-chemical parameters in both seasons (dry season and wet seasons) for water bodies as well as groundwater. The physical chemical parameters analysed were Sodium Adsorption Ratio (SAR), Soluble Sodium Percentage (SSP) Magnesium Adsorption Ratio (MAR) Kelly Index (KI) Total Hardness (TH), pH, the Electric conductivity (EC), Total Dissolved Solids (TDS). Our analyzed samples fall into permissible limit of irrigation water quality, the mean values of electrical conductivity were high. The knowledge from this study will be used in establishment of Nyandungu recreation park irrigating with water quality on gardens surrounding recreation park and local community.
\end{abstract}

\section{Keywords}

Wetlands, Irrigation Water Quality, Physico-Chemical Parameters

\section{Introduction}

Water quality refers to physical, chemicals and biological properties of water, this term is usually used to express suitability of water to sustain different uses or processes. Each particular use will have a definite requirement for chemical, physical and biological characteristics of water (Chapman et al., 1996). Polluted water has industrial effluent and Nyandungu wetland is in special economic 
zone as it is surrounded by industry hence sewage water can cause water born disease on agriculture productivity and negative effect on groundwater (REMA, 2016). Nyandungu wetland has been threatened by human activities mainly conversion to agriculture, human settlements, commercial and industrial activities reducing the flood and pollution reduction capacity of wetlands, currently Nyandungu is considered as a valuable ecosystem that provides a wildlife habitat, enhance water quality and flood controls since there is inadequate information on the existing water resource from the present excavated boreholes (REMA, 2016) the agricultural water needs quality to be addressed so that it will not cause the environmental pollution which may deteriorate agricultural produces, water quality is one factor responsible for agriculture productivity (Kijne, 2003). Urban wetlands are essential in preserving urban landscape it has a lot of ecological with social service function research have proved that urban parks are hugely important to human's well-being and urban ecosystems in general (McCarthy, 2006). Furthermore, studies showed that hydrological evaluation of wetlands will only be valid, if groundwater and its interaction with surface water are well addressed as well (Lapworth et al., 2017). The physico-chemical characteristics of groundwater may have water quality effect by referring to their levels that are subjective by period changes (Likambo, 2014). The Rwandan rainfall pattern is bi-seasonal having two rainy periods, the first season start from March to May and is less intense, and second wet season start from mid-September or early October through December to February characterized by irregular right rainfall (MINIRENA, 2013 Watershed Rehabilitation guidelines). This study was conducted to assess physical chemical parameters in seasons.

\section{Materials and Methods}

\subsection{Description of Study Area}

Nyandungu wetland is located in two districts of Kigali include Gasabo and kicukiro Ndera and Nyarugunga sector. Recreation park is 134 hectares a and a total perimeter of 6730.8 meters, Wetland is located in a low area of 1360 meters' altitude and it is dominated by hill, Rwimbogo, Masoro, Munini river are the surrounding location on the study area (Figure 1) culminate at $1480 \mathrm{~m}$ altitude it has more or less constant temperatures throughout the year $\left(16^{\circ} \mathrm{C}-17^{\circ} \mathrm{C}\right.$ in the high altitudes). Mean altitude equivalent to $1500 \mathrm{~m}$, is located in the equatorial region. Its tropical climate is characterized by long wet seasons and relatively low temperatures as a consequence of its altitude (Tsinda \& Abbott, 2012). The soils of Nyandungu valley are clay, silt and sand.

\subsection{Sample Size and Sampling Procedure}

In study area there exist a functional borehole and different water bodies sample was done in two different seasons in order to estimate the effect of seasonal variation of levels of physico-chemical parameters of both water bodies and groundwater of well. The wet seasons was done 29th to 30th April, 2020 when mean monthly rainfall for the month was $120 \mathrm{~m}$. Sampling carried out in dry 


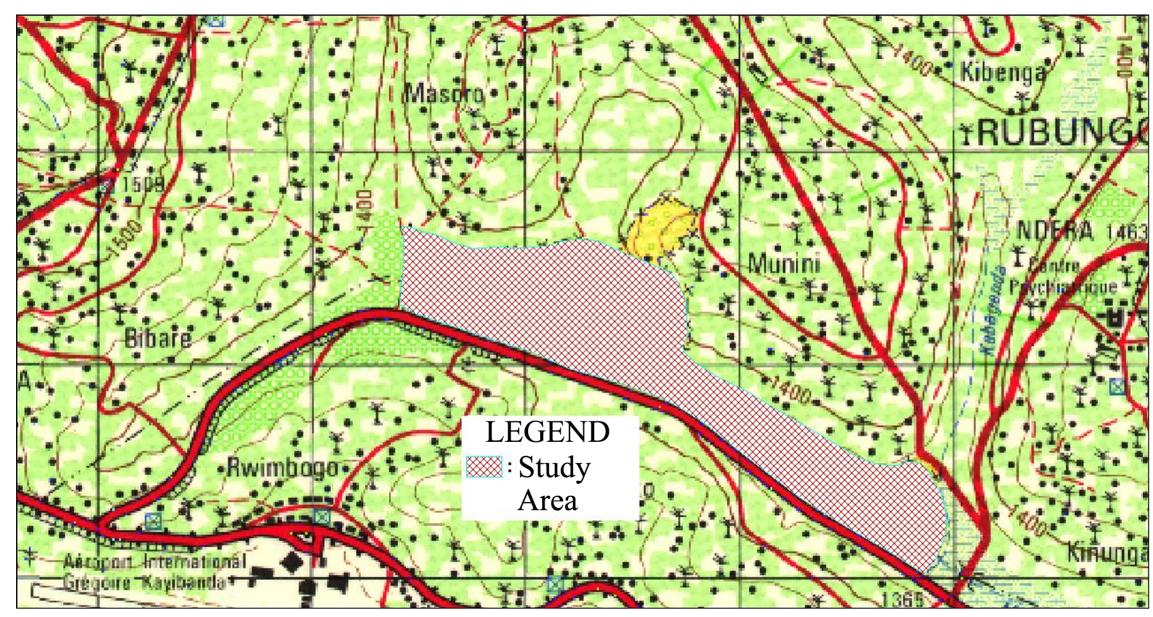

Figure 1. Nyandungu wetland study area.

season was done on 22 nd to 23 rd June, 2020 when the mean monthly rainfall was $40 \mathrm{~m}$. Sampling was carried out in the morning hours between $8 \mathrm{~h} 00 \mathrm{am}$ to $9 \mathrm{~h} 00 \mathrm{am}$ and evening period between $4 \mathrm{~h} 00 \mathrm{pm}$ and $5 \mathrm{~h} 00 \mathrm{pm}$ and 16 collected samples was soaked in dilute hydrochloric acid and rinsed twice in distilled water. The parameters were analyzed in Laboratory used by standards methods, SPSS was used to estimate descriptive statistics and variation of each physico-chemical parameters (Kothari, 2008).

\subsection{Sodium Adsorption Ratio (SAR)}

Sodium Adsorption Ratio refers to the degree of which sodium will be absorbed in the soil it is expressed in mill equivalents per litter (Grattan, 2002). In study area SAR ranged from 0.716 to 2.181 in dry season and 0.559 to 2.428 in wet season while the mean levels of SAR were 1.50 and 1.601 in dry season and wet season as shown in Table 1.

In study area SAR ranged from 0.716 to 2.181 in dry season and 0.559 to 2.428 in wet season while the mean levels of SAR were 1.50 and 1.601 in dry season and wet season. The results from the findings all agree with the report of FAO Standards indicates the water sites to be favorable for irrigation water qualities for irrigation which should range in international standards SAR less than 3 is suitable for irrigation, 10 up 18 is classified as Good while SAR greater than 26 is classified as unsuitable for irrigation as shown in Table 2. The findings from the present study conducted in Rwanda agree with the international standard as cited in (Grattan, 2002)

$$
\mathrm{SAR}=\frac{\mathrm{Na}^{+}}{\sqrt{\left(\mathrm{Ca}^{2+}+\mathrm{Mg}^{2+}\right) / 2}}
$$

where SAR: sodium adsorption ratio.

\subsection{Sodium Soluble Percentage}

Soluble Sodium Percentage (SSP) refers to the percentage of all cations made up 
Table 1. Variation of SAR in two seasons.

\begin{tabular}{ccc}
\hline Statistical Parameter & SAR/Dry season & SAR/wet season \\
\hline Mean & 1.5 & 1.601 \\
P50 & 1.52 & 1.701 \\
Var & 0.228 & 0.523 \\
SD & 0.477 & 0.723 \\
Min & 0.716 & 0.559 \\
Max & 2.181 & 2.428 \\
CV & 0.318 & 0.452 \\
N (Obs) & 8 & 8 \\
\hline
\end{tabular}

Table 2. Alkalinity levels.

\begin{tabular}{cc}
\hline SAR & Quality of water \\
\hline 2to less than 10 & Outstanding \\
10 up to 18 & Good \\
18 up to26 & Doubtful \\
Greater than 26 & Unsuitable \\
\hline
\end{tabular}

by sodium. Soluble sodium percentage is essential criteria in classifying water quality for irrigation. Sodium content of water reacts with soil thus reduce its permeability since it accumulates in pore space (Hem, 1991). Percentage of sodium is an expression of sodium content. The soluble sodium percentage in study area ranged $11.731 \%$ to $25.977 \%$ and $16.072 \%$ to $29.254 \%$ in dry season and wet season respectively while the mean levels of soluble sodium percentage were $19.915 \%$ and $24.583 \%$ in dry and wet season respectively as it is presented in $\mathrm{Ta}$ ble 3. Allowable sodium percentage gives the rights to the water to be used for irrigation because the max limit should be less than $60 \%$.

It is calculated by using the following formula:

$$
\% \mathrm{Na}=\frac{\mathrm{Na}^{+} * 100}{\mathrm{Ca}^{2+}+\mathrm{Mg}^{2+}+\mathrm{K}^{+}+\mathrm{Na}^{+}}
$$

\subsection{Magnesium Adsorption Ratio}

Magnesium and Calcium are generally in aquarium state in water when magnesium is high quantity in water it affects quality of soil. High content of magnesium water reduce crop yield since it converts soil nature into alkaline (Grattan, 2002). The Magnesium Adsorption Ratio in study area ranged $30.076 \%$ to $45.799 \%$ and $28.939 \%$ to $38.471 \%$ in dry season and wet season respectively while the mean levels of Magnesium Adsorption Ratio were $35.581 \%$ and $33.573 \%$ in dry and wet season respectively as presented in Table 4 . Magnesium ration above $50 \%$ is harmful to the plants (Grattan, 2002). It is calculated as follows. 
Table 3. SSP Variation in two season.

\begin{tabular}{ccc}
\hline Statistical Parameter & SSP/dry season & SSP/wet season \\
\hline Mean & 19.915 & 24.583 \\
P50 & 20.186 & 26.514 \\
Var & 20.421 & 27.264 \\
SD & 4.519 & 5.221 \\
Min & 11.731 & 16.072 \\
Max & 25.977 & 29.254 \\
CV & 0.227 & 0.212 \\
N (Obs) & 8 & 8 \\
\hline
\end{tabular}

Table 4. Variation of MAR in two seasons.

\begin{tabular}{ccc}
\hline Statistical Parameter & MAR/Dry season & MAR/wet season \\
\hline Mean & 35.581 & 33.573 \\
P50 & 33.264 & 32.544 \\
Var & 40.388 & 13.775 \\
SD & 6.355 & 3.711 \\
Min & 30.076 & 28.939 \\
Max & 45.799 & 38.471 \\
CV & 0.179 & 0.111 \\
N (Obs) & 8 & 8 \\
\hline
\end{tabular}

$$
\text { MAR }=\frac{\mathrm{Mg}^{2+} \times 100}{\mathrm{Ca}^{2+}+\mathrm{Mg}^{2+}}
$$

\subsection{Kelly Index/Kelly Ratio}

Kelly index is used to indicate the suitability of groundwater for irrigation in agriculture, irrigation water containing higher sodium affect soil structure hence reduced rate of water moves into the soil (Grattan, 2002). In study area Kelly index ranged from 0.1 to 0.319 and 0.077 to 0.298 in dry season and wet season respectively as shown in Table 5 .

The mean levels of Kelly index were 0.215 as well as 0.212 for both the dry and wet season the coefficient of variation were 0.336 also 0.415 in both dry and wet season (Table 5). When Kelly index is more than 1 it means water has an excess sodium level and therefore is considered not suitable for irrigation purposes (Kumar \& Kumar, 2012). It is expressed as

$$
\mathrm{KR}=\frac{\mathrm{Na}^{+}}{\mathrm{Ca}^{2+}+\mathrm{Mg}^{2+}}
$$

\subsection{Total Hardness}

There exist temporal and permanent hardness of water, temporal hardness of 
Table 5. Descriptive statistics of KI in two seasons.

\begin{tabular}{ccc}
\hline Statistical Parameter & TH/dry season & TH/wet season \\
\hline Mean & 602.445 & 687.937 \\
P50 & 605.365 & 643.355 \\
Var & 1714.87 & 11579.4 \\
SD & 41.411 & 107.607 \\
Min & 553.474 & 592.428 \\
Max & 657.044 & 859.381 \\
CV & 0.069 & 0.156 \\
N (Obs) & 8 & 8 \\
\hline
\end{tabular}

water overcomes when anion is carbonate and boiling remove it. When anions are nitrates, sulfates and chlorides they cause permanent hardness that boiling can't remove it. Usually groundwater is hard compared to surface water and may possess levels higher than permissible limits due to high solubilizing with constituents of the rock like dolomite, calcite and gypsum. Runoff from limestone soil partials, textile, materials comprising magnesium and sewage are the main source of hardness (Olumuyiwa et al., 2012).

In study area total Hardness ranged from 553.474 to 657.044 and 592.428 to 859.381 in dry season and wet season respectively as shown in Table 6.

The mean levels of Total Hardness were 602.445 and 687.937 in dry and wet season respectively (Table 6) the coefficient of variation were 0.069 and 0.156 in dry and wet season respectively. Hard water prevents lather formation with soap (Onwughara et al., 2013). In this study was calculated using the following formula:

$$
\mathrm{TH}=\left(\mathrm{Ca}^{2+}+\mathrm{Mg}^{2+}\right) \times 50
$$

\subsection{Variation of $\mathrm{pH}$}

$\mathrm{pH}$ refers to the measurement of hydrogen potentiality in water. Globally hydrogen potential defines the level of alkalinity or acidity of solution and it is an indication of chemical reaction of water (Murhekar, 2011). The $\mathrm{pH}$ Values measured in water bodies and public borehole varied right through the study. The values ranged 5.60 to 7.5 in dry season and also 5.9 to 6.7 in wet season with corresponding average of 6.55 as shown in Table 7 in whole area. $\mathrm{pH}$ is one of chemical properties that determine water quality for irrigation (Hem, 1991).

\subsection{Electric Conductivity}

Electrical conductivity is used for indicating overall concentration of ionized water constituents means ions and cations (Onwughara et al., 2013). The increase of electrical conductivity is due to increase of ionized salts consequently affect crop yield due to low sees germination (Onwughara et al., 2013). Electric conductivity (EC) values in study area ranged from 380.3 to $1220.55 \mu \mathrm{S} / \mathrm{cm}$ during dry season 280.40 to $996.600 \mu \mathrm{S} / \mathrm{cm}$ in wet as shown in Table 8 . 
Table 6. Descriptive statistics of total hardness in two seasons.

\begin{tabular}{ccc}
\hline Statistical Parameter & TH/dry season & TH/wet season \\
\hline Mean & 602.445 & 687.937 \\
P50 & 605.365 & 643.355 \\
Var. & 1714.87 & 11579.4 \\
SD & 41.411 & 107.607 \\
Min & 553.474 & 592.428 \\
Max & 657.044 & 859.381 \\
CV & 0.069 & 0.156 \\
N (Obs.) & 8 & 8 \\
\hline
\end{tabular}

Table 7. Descriptive statistics of $\mathrm{pH}$ in two seasons.

\begin{tabular}{ccc}
\hline Statistical parameter & Dry season & Wet season \\
\hline Mean & 6.815 & 6.3 \\
P50 & 6.885 & 6.25 \\
Var & 0.331 & 0.077 \\
SD & 0.575 & 0.278 \\
Min & 5.6 & 5.9 \\
Max & 7.5 & 6.7 \\
CV & 0.084 & 0.044 \\
N (Obs) & 8 & 8 \\
\hline
\end{tabular}

The findings also agree with the research findings conducted by (Arefin et al., 2016) where they confirmed that EC averages were $288.60 \mu \mathrm{S} / \mathrm{cm}$. For irrigation water suitability if the value is less than $250 \mu \mathrm{S} / \mathrm{cm}$ is classified in excellent range as shown in Table 9 while if it is greater than $2250 \mu \mathrm{S} / \mathrm{cm}$ is classified as unsuitable for irrigation.

Suitability Electrical Conductivity of irrigation water according to Wallender \& Tanji (2012).

\subsection{Total Dissolved Solids}

TDS describe the total amount of inorganic substances like magnesium salts, calcium salts, sodium salts etc. and small organic matter (OM) existing in water. Increase of TDS in water indicates that water constitute minerals from rock constituents (Buridi \& Gedala, 2014). In study area values of TDS ranged between 132.60 and $490.68 \mathrm{mg} / \mathrm{l}$ during dry season also 169.80 to $512.25 \mathrm{mg} / \mathrm{l}$ in wet period as shown in Table 10.

Whole tested samples were less than $1000 \mathrm{mg} / \mathrm{l}$ was an indication of freshwater (Freeze, 1971). 
Table 8. Descriptive statistics of EC in two seasons.

\begin{tabular}{ccc}
\hline Statistical parameter & Wet season & Dry season \\
\hline Mean & 743.544 & 802.764 \\
P50 & 849.725 & 820.41 \\
Var & 86209.4 & 90586.6 \\
SD & 293.614 & 300.976 \\
Min & 280.4 & 380.3 \\
Max & 995.6 & 1220.55 \\
CV & 0.395 & 0.375 \\
N (Obs) & 8 & 8 \\
\hline
\end{tabular}

Table 9. Degree of EC to suitability of water quality.

\begin{tabular}{cc}
\hline Quality of water & Electrical conductivity $(\mu \mathrm{S} / \mathrm{cm})$ \\
\hline Excellent range & Less than 250 \\
Good & $250-750$ \\
Doubtful class & $750-2250$ \\
Unsuitable range & Greater than 2250
\end{tabular}

Table 10. Descriptive statistics of TDS in two seasons.

\begin{tabular}{ccc}
\hline Statistical parameter & Dry season & Wet season \\
\hline Mean & 266.148 & 288.664 \\
P50 & 220.025 & 237.175 \\
Var. & 20541.5 & 19566.8 \\
SD & 143.323 & 139.881 \\
Min & 132.6 & 169.8 \\
Max & 490.68 & 512.25 \\
CV & 0.539 & 0.485 \\
N (Obs.) & 8 & 8 \\
\hline
\end{tabular}

\section{Conclusion}

It was obvious from analysis of our results $80 \%$ of our analyzed samples fall into permissible limit of irrigation water quality, the mean values of electrical conductivity were high 802.764 and $743.544 \mu \mathrm{S} / \mathrm{cm}$ in dry and wet season respectively therefore it is classified in doubtful class there is negative relationship between EC and crop growth. The relationship is more negative with salt sensitive plants it is recommended not to cultivate crop sensitive to salts. SAR values were less than 10 classifying groundwater and surface water in wetlands in irrigation class of excellence. While mean levels for Magnesium Adsorption Ratio were $35.581 \%$ and $33.573 \%$ in dry and wet season respectively and it is good for irrigation water for both seasons. The mean levels of Total Hardness were 602.445 
and 687.937 in dry and wet season respectively; the mean levels of Kelly index were 0.215 and 0.212 in dry and wet season respectively.

\section{Conflicts of Interest}

The authors declare no conflicts of interest regarding the publication of this paper.

\section{References}

Arefin, T. M., Rahman, M. M., Wahid-U-Zzaman, M., \& Kim, J.-E. (2016). Heavy Metal Contamination in Surface Water Used for Irrigation, Functional Assessment of the Turag River in Bangladesh. Journal of Applied Biological Chemistry, 59, 83-90. https://doi.org/10.3839/jabc.2016.015

Buridi, K. R., \& Gedala, R. K. (2014) Study on Determination of Physicochemical Parameters of Ground Water in Industrial Area of Pydibheemavaram, Vizianagaram District, Andhrapradesh, India. Austin Journal of Public Health and Epidemiology, 1, 1008.

Chapman, D. V., World Health Organization, UNESCO \& United Nations Environment Programme (1996). Water Quality Assessments: A Guide to the Use of Biota, Sediments and Water in Environmental Monitoring (2nd Ed.). E \& FN Spon.

Freeze, R. A. (1971). Three-Dimensional, Transient, Saturated-Unsaturated Flow in a Groundwater Basin. Water Resources Research, 7, 347-366. https://doi.org/10.1029/WR007i002p00347

Grattan, S. (2002). Irrigation Water Salinity and Crop Production. University of California, Division of Agriculture and Natural Resources. http://anrcatalog.ucdavis.edu https://doi.org/10.3733/ucanr.8066

Hem, J. D. (1991). Study and Interpretation of the Chemical Characteristics of Natural Water. Scientific Publishers.

Kijne, J. W. (2003). Water Productivity under Saline Conditions. In J. W. Kijne, R. Barker, \& D. Molden (Eds.), Water Productivity in Agriculture: Limits and Opportunities for Improvement (pp. 89-102). CABI. https://doi.org/10.1079/9780851996691.0000

Kothari, C. R. (2008). Research Methodology-Methods and Techniques. New Age International.

Kumar, M., \& Kumar, R. (2012). Assessment of Physico-Chemical Properties of Ground Water in Granite Mining Areas in Jhansi, U.P. International Journal of Engineering Research and Technology, 1, 1-9.

Lapworth, J. D. et al. (2017). Urban Groundwater Quality in Sub-Saharan Africa: Current Status and Implications for Water Security and Public Health. Hydrogeology Journal, 25, 1093-1116. https://doi.org/10.1007/s10040-016-1516-6

Likambo, W. (2014). Assessment of Borehole Water Quality and Consumption in Yei County, South Sudan. Unpublished Master's Thesis, Makarere University.

McCarthy, T. (2006). Groundwater in the Wetlands of the Okavango Delta, Botswana, and Its Contribution to the Structure and Function of the Ecosystem. Journal of Hydrology, 320, 264-282. https://doi.org/10.1016/j.jhydrol.2005.07.045

MINIRENA (2013). Watershed Rehabilitation guidelines. Kigali: MINIRENA.

Murhekar, G. H. (2011). Determination of Physico-Chemical Parameters of Surface Water Samples. Akot City, India. International Journal of Current Research and Academic Review, 2, 31-41. 
Olumuyiwa, L. F., Otieno, F. A. O., \& Ochieng, G. M. (2012). Characteristics, Qualities, Pollutions and Treatments of Water in Durban. International Journal of Water Resources and Environmental Engineering, 4, 162-170.

Onwughara, N. I., Ajiwe, V. I. E., \& Nnabuenyi, H. O. (2013). Physicochemical Studies of Water from Selected Boreholes in Umuahia North Local Government Area, in Abia State, Nigeria. International Journal of Pure \& Applied Bioscience, 1, 34-44.

REMA (2016). National Climate Change and Environment Fund (FONERWA) Full Project Document (PD). Kigali.

Tsinda, A., \& Abbott, P. (2012) Catalysing Self-Sustaining Sanitation Chains in Informal Settlements: A Review and Analysis of the Situation Pertaining to the Provision of Sanitation to Low-Income Settlements in Kigali City (Rwanda): Diagnostic Report. IPAR-Rwanda. https://opendocs.ids.ac.uk/opendocs/handle/20.500.12413/9620

Wallender, W. W., \& Tanji, K. K. (2012) Agricultural Salinity Assessment and Management. American Society of Civil Engineers (ASCE).

https://doi.org/10.1061/9780784411698 